\title{
Gastroesophageal reflux and antacid therapy in IPF: analysis from the Australia IPF Registry
}

Helen E. Jo $0^{1,2,3^{*}} \mathbb{D}$, Tamera J. Corte $\mathrm{e}^{1,2,3}$, lan Glaspole ${ }^{3,4,5}$, Christopher Grainge ${ }^{3,6}$, Peter M. A. Hopkins ${ }^{3,7,8}$, Yuben Moodley ${ }^{3,9}$, Paul N. Reynolds ${ }^{10}$, Sally Chapman ${ }^{10}$, E. Haydn Walters ${ }^{3,11}$, Christopher Zappala ${ }^{12}$, Heather Allan ${ }^{13}$, Gregory J. Keir ${ }^{14}$, Wendy A. Cooper ${ }^{2,15,16}$, Annabelle M. Mahar ${ }^{15}$, Samantha Ellis ${ }^{17}$, Sacha Macansh ${ }^{13}$ and Nicole S. Goh ${ }^{3,18,19}$

\begin{abstract}
Background and objective: Gastroesophageal reflux disease (GORD) is highly prevalent in idiopathic pulmonary fibrosis (IPF) and may play a role in its pathogenesis. Recent IPF treatment guidelines suggest that all patients with IPF be considered for antacid therapy. However, emerging evidence suggests that antacid therapy does not improve IPF patient outcomes and may increase the risk of pulmonary infection.

Methods: Using prospectively collected data from the Australian IPF Registry including use of antacid therapy, GORD diagnosis and GORD symptoms, the relationship of these GORD variables to survival and disease progression was assessed. The severity of GORD symptoms using the frequency scale for symptoms of GORD (FSSG) and its relationships to outcomes was also assessed for the first time in an IPF cohort.

Results: Five hundred eighty-seven (86\%) of the 684 patients in the Australian IPF Registry were eligible for inclusion. Patients were mostly male (69\%), aged $71.0 \pm 8.5$ years with moderate disease (FVC $81.7 \pm 21.5 \%$; DLco $48.5 \pm 16.4 \%)$. Most patients were taking antacids $(n=384 ; 65 \%)$, though fewer had a diagnosis of GORD ( $n=243,41.4 \%)$ and typical GORD symptoms were even less common $(n=171,29.1 \%)$. The mean FSSG score was $8.39 \pm 7.45$ with $43 \%(n=251)$ having a score $>8$. Overall, there was no difference in survival or disease progression, regardless of antacid treatment, GORD diagnosis or GORD symptoms.

Conclusions: Neither the use of antacid therapy nor the presence of GORD symptoms affects longer term outcomes in IPF patients. This contributes to the increasing evidence that antacid therapy may not be beneficial in IPF patients and that GORD directed therapy should be considered on an individual basis to treat the symptoms of reflux.
\end{abstract}

Keywords: Idiopathic pulmonary fibrosis, Gastroesophageal reflux disease, Antacid, Registry, Cough

\section{Introduction}

Despite recent treatment advances [1, 2], idiopathic pulmonary fibrosis (IPF) remains an irreversible fibrotic lung disease associated with a poor survival [3]. While IPF is limited to the lungs, co-morbidities are common in this population and many studies have shown that gastroesophageal reflux (GOR) is highly prevalent [4-7],

\footnotetext{
* Correspondence: helen.jo@sydney.edu.au

'Department of Respiratory Medicine, Royal Prince Alfred Hospital, Missenden Road, Camperdown, Sydney, NSW 2050, Australia

${ }^{2}$ Faculty of Medicine, University of Sydney, Sydney, NSW, Australia Full list of author information is available at the end of the article
}

may contribute to pathogenesis and is reported to be associated with a better survival $[8,9]$. Gastroesophageal reflux disease (GORD) is defined as the presence of troublesome gastroesophageal reflux symptoms (at least twice a week) and/or complications including oesophageal injury $[10,11]$. However, given the subjective nature of symptoms, the accurate diagnosis of GORD remains elusive. While objective testing for oesophageal injury at endoscopy can be performed, there is poor correlation with reflux symptoms. Only $39 \%$ of patients with oesophageal injury reported typical reflux symptoms in one study, and more than $60 \%$ of patients who

(c) The Author(s). 2019 Open Access This article is distributed under the terms of the Creative Commons Attribution 4.0 International License (http://creativecommons.org/licenses/by/4.0/), which permits unrestricted use, distribution, and reproduction in any medium, provided you give appropriate credit to the original author(s) and the source, provide a link to the Creative Commons license, and indicate if changes were made. The Creative Commons Public Domain Dedication waiver (http://creativecommons.org/publicdomain/zero/1.0/) applies to the data made available in this article, unless otherwise stated. 
reported reflux symptoms had no evidence of oesophageal injury [12]. Twenty four hour ambulatory $\mathrm{pH}$ has also been used as an objective measure of GOR, although only $25 \%$ of patients with abnormal acid reflux on testing reported typical GORD symptoms [7]. Additionally, ambulatory $\mathrm{pH}$ monitoring cannot detect the presence of non-acid reflux, which may have important clinical implications, further limiting the utility of this test.

Current IPF treatment guidelines make a conditional recommendation for considering antacid therapy for all IPF patients irrespective of GORD symptoms [13]. This was based on early retrospective data demonstrating improved survival [8] and slowing disease progression [14] in IPF patients on antacid therapy. Subsequent post-hoc analyses from both the pirfenidone $[15,16]$ and nintedanib [17] studies, have demonstrated no benefit of antacid therapy on longer term outcomes for either the placebo [15] or treatment [16] populations, calling into question this recommendation.

Using data from the Australian IPF Registry, we explored: 1) the use of antacid therapy in our IPF population; and 2) the presence of GORD symptoms and disease, on disease progression and survival. For the first time in IPF, we also utilised the frequency scale for symptoms of GORD (FSSG) which was developed to predict the presence of endoscopic features and severity of oesophagitis resulting from GORD [18]. If clinically meaningful, this questionnaire may be a simple way to predict prognosis and treatment in IPF without resorting to invasive testing.

\section{Methods}

\section{Population}

All participants from the Australian IPF Registry who had completed questionnaires regarding co-morbidities, treatment and reflux symptoms were included in the study. The Australian IPF Registry is a prospective national registry which was established in 2012 for patients with IPF across Australia. Demographic, questionnaire and objective investigational data are collected at baseline and six-monthly during follow up. Details of the Registry have been published previously [19]. The data analysis for this study has ethical approval from the Sydney Local Health District ethics committee (protocol number X14-0264).

\section{GORD related variables}

In the baseline Registry questionnaire, all Registry participants are routinely asked about the following:

1. Diagnosis of GORD (Yes/No)

2. Typical GORD symptoms of heartburn, reflux or sour taste in mouth after eating (Yes/No)

3. List of current medications
4. Frequency scale for the symptoms of GORD (FSSG) (Table 1). A symptom score of $>8 / 48$ was used to define significant symptoms in categorical analysis based on previously reported data regarding accuracy in diagnosing endoscopic oesophagitis [18].

\section{Statistical analysis}

Results are presented as mean \pm standard deviation (SD), median and interquartile range (IQR) or $\mathrm{n}(\%)$ as appropriate. Comparisons between groups were made using Student's t test or chi squared. An unstructured, linear mixed model with random intercepts and slopes was used to calculate the annual decline in FVC \% predicted. Survival analysis was performed with Cox proportional hazards and Kaplan Meier methodology. All results with a $p$ value $<0.05$ are reported as significant.

\section{Results}

\section{Baseline characteristics}

Of the 684 patients in the Registry at the time of this analysis, 587 (86\%) patients had completed the baseline questionnaire. The characteristics of this population were typical for IPF with most patients being older $(71.0 \pm 8.5$ years), mostly male ( $n=406 ; 69 \%)$ and ex/current smokers $(n=424 ; 72 \%)$ (Table 2). The majority of patients were taking antacid therapy $(n=384 ; 65 \%)$ at the time of entry into the Registry, with most receiving proton pump inhibitors (PPIs) $(n=344,90.0 \%)$, and fewer receiving Histamine- 2 receptor antagonists (H2RA) $(n=10,2.6 \%)$ and a small proportion on both PPIs and H2RAs $(n=30$, $7.8 \%$ ). Of those receiving antacid treatment, 193 patients (50\%) had significant symptoms (FSSG> 8) while 191 patients (50\%) reported less significant reflux symptoms $(\mathrm{FSSG} \leq 8)$. The self-reported prevalence of GORD was $41.4 \%(n=243)$ but only $29.1 \%(n=171)$ reported typical symptoms of "heartburn, reflux or sour taste in mouth after eating". The mean FSSG score was 8.39/48 (SD 7.45), with $43 \%(n=251)$ patients having a FSSG score $>8$.

\section{Disease progression and overall survival}

During a median follow up period of 2.2 years (IQR 1.3 to 3.4 years), 240 (40.9\%) patients died and $33(5.6 \%)$ had a lung transplant.

There was no difference in the annual fall in FVC \%predicted demonstrated, regardless of whether patients were receiving antacid therapy (compared to those not on therapy), or had a GORD diagnosis (compared to those without a diagnosis of GORD), or had significant GORD symptoms (FSSG $>$ 8) (compared to those without significant GORD symptoms (FSSG $\leq 8$ ) (Table 3 ).

On univariable analysis for mortality, there was also no difference between patients who were receiving antacid treatment compared to those not receiving antacid treatment (Table 4). There was also no association 
Table 1 Frequency scale for the symptoms of GORD (FSSG)

\begin{tabular}{|c|c|c|c|c|c|}
\hline & Never & Occasionally & Sometimes & Often & Always \\
\hline 1. Do you get heartburn? & 0 & 1 & 2 & 3 & 4 \\
\hline 2. Does your stomach get bloated? & 0 & 1 & 2 & 3 & 4 \\
\hline 3. Does your stomach ever feel heavy after meals? & 0 & 1 & 2 & 3 & 4 \\
\hline 4. Do you sometimes subconsciously rub your chest with your hand? & 0 & 1 & 2 & 3 & 4 \\
\hline 5. Do you ever feel sick? & 0 & 1 & 2 & 3 & 4 \\
\hline 6. Do you get heartburn after meals? & 0 & 1 & 2 & 3 & 4 \\
\hline 7. Do you have an unusual (eg burning) sensation in your throat? & 0 & 1 & 2 & 3 & 4 \\
\hline 8. Do you feel full while eating meals? & 0 & 1 & 2 & 3 & 4 \\
\hline 9. Do some things get stuck when you swallow? & 0 & 1 & 2 & 3 & 4 \\
\hline 10. Do you get bitter liquid (acid) coming up into your throat? & 0 & 1 & 2 & 3 & 4 \\
\hline 11. Do you burp a lot? & 0 & 1 & 2 & 3 & 4 \\
\hline 12. Do you get heartburn if you bend over? & 0 & 1 & 2 & 3 & 4 \\
\hline
\end{tabular}

Total Acid reflux symptoms (total $=48$ )

Total Dyspeptic (dysmotility) symptoms (total $=20$ )

Total Dyspeptic (dysmotility) symptoms are in bold

between the presence of a GORD diagnosis or significant GORD symptoms with overall survival (Fig. 1).

On multivariable analysis, there was no difference in survival between antacid therapy groups $\mathrm{HR}=1.02 ; 95 \% \mathrm{CI}$ $0.72-1.43 ; p=0.928$ ), adjusting for age, gender, smoking, FVC \%predicted and DLco \%predicted. Increasing age, reducing FVC \%predicted and DLco \%predicted levels, were independent predictors of worse overall survival.

In the subgroup of 384 patients receiving antacid therapy, there was also no difference in survival $(\mathrm{HR}=0.88,95 \% \mathrm{CI}$ $=0.64,1.20 ; p=0.415)$ between those with significant GORD symptoms (FSSG> 8 ), compared to those without
(FSSG $\leq 8$ ) significant GORD symptoms (Fig. 2). There was also no difference in survival based on GORD diagnosis or typical GORD symptoms.

\section{Discussion}

This is one of the largest retrospective cohort studies of antacid therapy in IPF and is the first study to utilise the FSSG score to assess GORD symptom severity in patients with IPF. In this analysis of real-world IPF patients from the Australian IPF Registry, treatment with antacid therapy did not have any impact on either IPF disease progression or survival, regardless of the presence of

Table 2 Clinical characteristics and prevalence of GORD related features

\begin{tabular}{|c|c|c|c|c|c|c|c|c|}
\hline & \multirow{2}{*}{$\begin{array}{l}\mathrm{n} \\
587\end{array}$} & \multirow[t]{2}{*}{ overall } & \multirow[t]{2}{*}{ SD or $\%$} & \multicolumn{2}{|l|}{ antacid } & \multicolumn{2}{|c|}{ no antacid } & \multirow[t]{2}{*}{$p$} \\
\hline & & & & 384 & $65 \%$ & 203 & $35 \%$ & \\
\hline Age & 586 & 71.0 & 8.5 & 71.6 & 8.2 & 69.7 & 8.8 & 0.008 \\
\hline male & 587 & 406 & $69 \%$ & 258 & $67 \%$ & 148 & $73 \%$ & NS \\
\hline Ever smoker & 587 & 424 & $72 \%$ & 280 & $73 \%$ & 144 & $75 \%$ & NS \\
\hline $\mathrm{BMI}$ & 450 & 28.9 & 4.8 & 28.8 & 4.5 & 29.0 & 5.4 & NS \\
\hline $\mathrm{FVC}(\mathrm{L})$ & 462 & 2.6 & 0.8 & 2.6 & 0.77 & 2.6 & 0.76 & NS \\
\hline FVC (\%pred) & 462 & $81.7 \%$ & $21.4 \%$ & $83.6 \%$ & $22.6 \%$ & $78.3 \%$ & $18.8 \%$ & 0.009 \\
\hline DLco (\%pred) & 409 & $48.5 \%$ & $16.4 \%$ & $49.8 \%$ & $16.1 \%$ & $46.1 \%$ & $16.6 \%$ & 0.027 \\
\hline $\mathrm{CPI}$ & 405 & 44.93 & 13.88 & 43.83 & 14.16 & 46.87 & 13.19 & 0.034 \\
\hline SGRQ & 550 & 47.6 & 20.5 & 48.57 & 20.5 & 45.2 & 20.7 & 0.072 \\
\hline FSSG symptom score & 587 & 8.4 & 7.5 & 9.7 & 7.9 & 5.9 & 5.7 & $<0.001$ \\
\hline GORD typical symptoms & 587 & 171 & $29 \%$ & 139 & $36 \%$ & 32 & $16 \%$ & $<0.001$ \\
\hline GORD disease & 587 & 243 & $41 \%$ & 208 & $54 \%$ & 35 & $17 \%$ & $<0.001$ \\
\hline FSSG $>8$ & 587 & 251 & $43 \%$ & 193 & $50 \%$ & 58 & $29 \%$ & $<0.001$ \\
\hline
\end{tabular}

BMI Body Mass Index, FVC Forced Vital Capacity, DLco diffusion capacity for carbon monoxide, CPI composite physiological index, GORD gastroesophageal reflux disease, SGRQ St George's Respiratory Questionnaire, FSSG frequency scale for the symptoms of GORD 
Table 3 Annual decline in FVC\% predicted by GORD variable

\begin{tabular}{llllll}
\hline GORD variable & Yes $(95 \% \mathrm{Cl})$ & \multicolumn{1}{l}{ No $(95 \% \mathrm{Cl})$} & $p$ \\
\hline Antacid therapy & $4.0 \%$ & $3.3,4.8 \%$ & $3.7 \%$ & $2.7,4.7 \%$ & 0.614 \\
GORD diagnosis & $4.6 \%$ & $3.5,5.4 \%$ & $3.5 \%$ & $2.7,4.4 \%$ & 0.162 \\
Typical reflux symptoms & $4.0 \%$ & $3.0,5.1 \%$ & $3.7 \%$ & $3.0,4.4 \%$ & 0.612 \\
FSSG>8 & $4.5 \%$ & $3.5,5.4 \%$ & $3.5 \%$ & $2.7,4.4 \%$ & 0.153 \\
\hline
\end{tabular}

reflux symptoms. There was also no association between either the presence of typical reflux symptoms nor symptom severity with IPF disease progression or survival. In the absence of prospective, randomised controlled trials showing benefit of antacid medications in IPF, this study suggests that antacid therapy should not be recommended broadly for the treatment of IPF patients.

There has been extensive debate regarding the utility of antacid therapy in IPF. A retrospective analysis of 204 patients by Lee et al. [8] showed that reported use of antacid therapy was associated with decreased radiological fibrosis and was an independent predictor of longer survival. Patients with typical reflux symptoms (heartburn or regurgitation) as well as those with patient or physician reported GORD diagnosis, were also found to have improved survival [8]. Unlike the study by Lee et al. [8], our study of 587 IPF patients did not show any association between GORD diagnosis, reflux symptoms or antacid therapy with survival. Similar to the post-hoc analysis of the 624 patients on placebo [15] and 623 patients on pirfenidone [16], we found that there was no difference in disease progression or survival in patients on antacid therapy. This however, is in contrast to the post-hoc analysis of 242 patients from the IPFnet trials which showed patients on antacid therapy had a slower decline in FVC [14]. In a recent meta-analysis [20], treatment of GORD was associated with a reduction in IPF-related mortality but not all cause mortality. The authors report however, that the quality of evidence was low and was based on 3 studies [15, 16, 21]. Given the

Table 4 Univariable Cox analysis for Overall

\begin{tabular}{|c|c|c|c|c|}
\hline \multirow[b]{2}{*}{ Age } & \multirow{2}{*}{$\begin{array}{l}\frac{H R}{1.03} \\
\end{array}$} & \multicolumn{2}{|c|}{$95 \% \mathrm{Cl}$} & \multirow{2}{*}{$\begin{array}{l}P \\
0.001\end{array}$} \\
\hline & & 1.01 & 1.04 & \\
\hline male & 1.34 & 1.01 & 1.79 & 0.043 \\
\hline smoker & 1.39 & 1.03 & 1.87 & 0.032 \\
\hline BMI & 0.95 & 0.92 & 0.98 & 0.002 \\
\hline FVC $\%$ predicted $^{a}$ & 0.78 & 0.72 & 0.84 & $<0.001$ \\
\hline DLco $\%$ predicted $^{a}$ & 0.56 & 0.5 & 0.63 & $<0.001$ \\
\hline GORD treatment & 0.99 & 0.75 & 1.31 & NS \\
\hline GORD typical symptoms & 0.88 & 0.66 & 1.16 & NS \\
\hline GORD disease & 1.07 & 0.83 & 1.39 & NS \\
\hline FSSG score $>8$ & 0.85 & 0.66 & 1.10 & NS \\
\hline
\end{tabular}

${ }^{a}$ for every 10 unit change; BMI Body Mass Index, FVC Forced Vital Capacity, $D L c o$ diffusion capacity for carbon monoxide, GORD gastroesophageal reflux disease, FSSG frequency scale for the symptoms of GORD

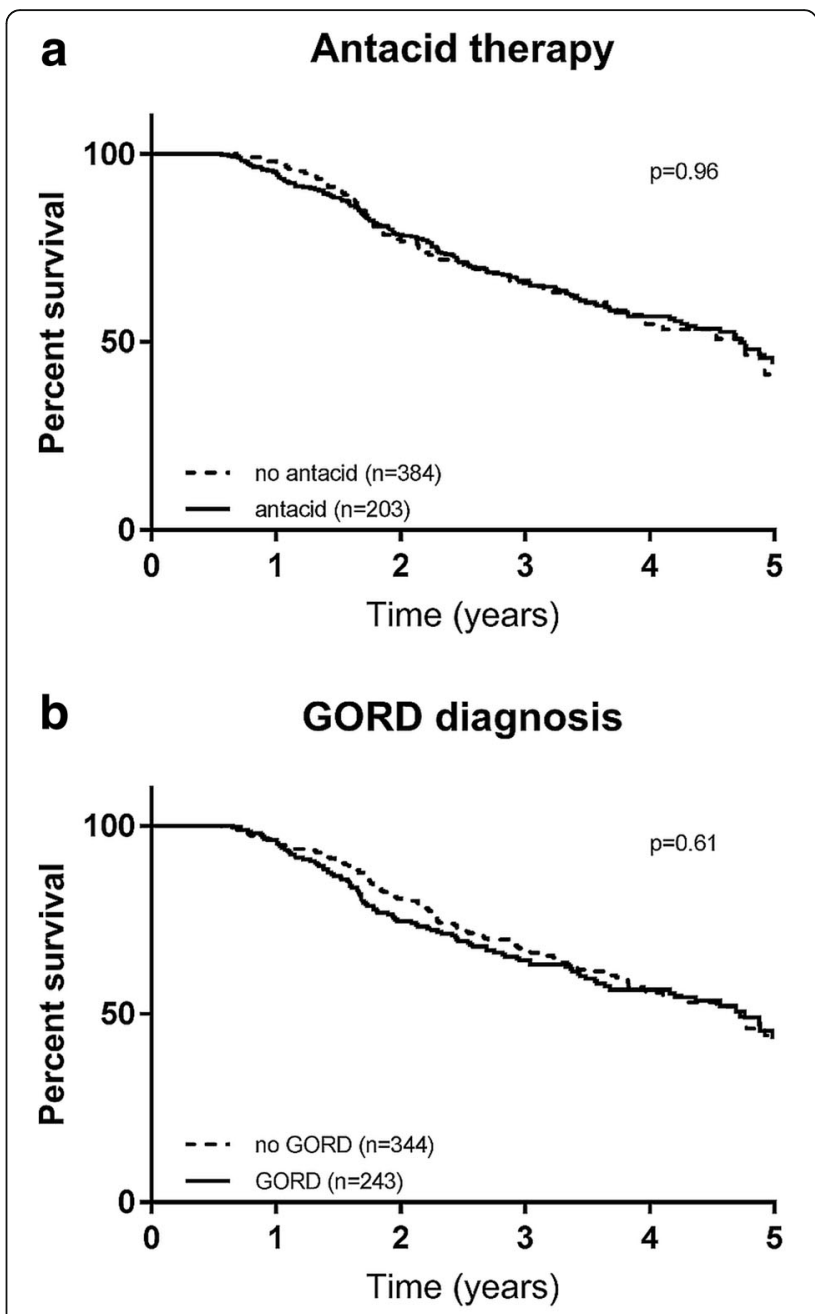

\section{Crequency scale for symptoms of GORD}

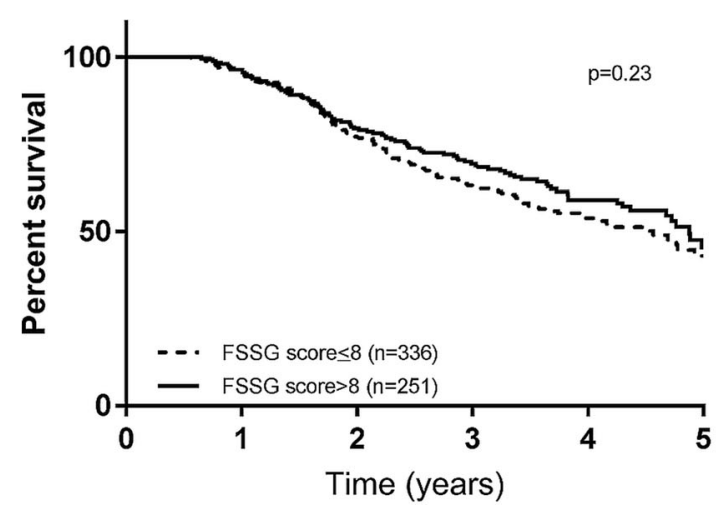

Fig. 1 Kaplan Meier analysis for overall survival. a. Antacid therapy b. Gastroesophageal disease diagnosis c. Frequency scale for the symptoms of GORD (FSSG) 


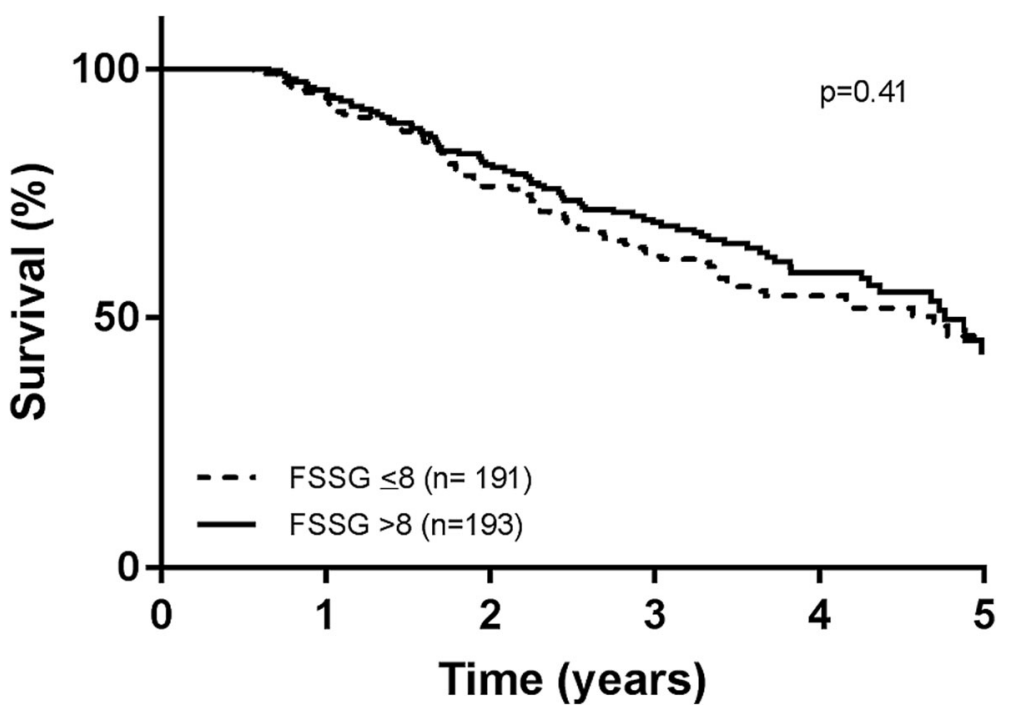

Fig. 2 Kaplan Meier analysis for overall survival in patients on antacid therapy by presence of symptoms

conditional recommendation for antacid therapy in the 2011 and 2015 IPF treatment guidelines [13], our study highlights the need for prospective randomised, controlled studies in this controversial area.

The conflicting results surrounding antacid therapy in IPF may reflect the contribution of non-acid reflux in the pathogenesis of IPF. While it has been postulated that micro-aspiration of acid results in lung injury, refluxate in GORD also contains other potentially harmful substances such as bile salts, enzymes and bacteria [22]. A study of bronchoalveolar lavage (BAL) showed an increase in pepsin and bile acids in patients with IPF ( $n=13 / 16)$ compared to patients with other interstitial lung diseases (ILDs) $(n=5 / 20)$ and those with no ILD $(n=0 / 16)$ [6]. Animal studies have shown that acid aspiration can cause collagen deposition and disruption of parenchymal architecture [23], while others have shown parenchymal fibrosis in chronic aspiration is independent of acidity [24]. The reflux of non-acid substance may not result in symptoms nor respond to antacid therapy, while still causing lung injury and explain the lack of association between symptoms and antacid treatment with IPF outcomes.

Anti-reflux surgery would prevent the reflux of both acid and non-acid refluxate and thus a prospective, randomised controlled trial to compare the decline in FVC between surgery and non-surgery groups has been performed. In this study of 58 IPF patients, patients who had surgery had a slower decline in FVC over 48 weeks (50mLs) compared to those who did not have surgery $(130 \mathrm{mLs})$. However this difference did not reach statistical significance $(p=0.28)$, and has been ascribed possibly to the small sample size [25]. With a recent meta-analysis of case control studies suggesting that the association between IPF and GORD may not be directly causal but be explained by confounding factors, particularly with smoking, the recommendation to broadly treat GORD in IPF is further brought into question [26].

Another major problem facing the investigation of the relationship between GORD and IPF is the subjective nature of the GORD definition. While GORD is defined as the presence of troublesome symptoms and/ or complications [11, 27], "troublesome symptoms" are subjective and whether the presence of cough in IPF fits this criteria is highly debatable [28]. In this study, we used the standardised FSSG questionnaire to characterise the severity of reflux symptoms in patients with IPF. The FSSG questionnaire was initially developed by screening 50 symptom questions to a group of 124 patients with an endoscopic diagnosis of oesophagitis. 12 questions were then selected and validated in a separate cohort of patients with and without GORD. They reported a sensitivity of $62 \%$, a specificity of $59 \%$ and accuracy of $60 \%$ at a score of $8 / 48$ for the presence of endoscopically visible reflux oesophagitis [18]. The relatively low accuracy of this score again reflects the subjective nature of symptoms. That said, compared to other studies where the rate of oesophagitis was $38.7 \%$ in patients who had typical symptoms [12] and $21.4 \%$ in patients with a GORD diagnosis [21], the FSSG questionnaire appeared to have greater accuracy. Improvement in endoscopic oesophagitis that were mirrored by improvements in FSSG scores is also encouraging as to the utility of this score [18]. In our study, there was no relationship between this questionnaire and IPF outcomes, suggesting that the FSSG questionnaire may be of use when considering treatment with antacid therapy for reflux oesophagitis without the need for endoscopy, but is not helpful in 
differentiating patients at greater risk for IPF disease progression or death.

Due to the retrospective nature of this study, there are several limitations. Firstly, the diagnosis of GORD was self-reported and may under or overestimate prevalence. For this reason, we looked at many GORD related variables to assess the impact of GORD and GORD treatment. Secondly, all antacid use was self-reported at baseline and analysed using an intention to treat approach. This approach does not reflect ongoing use nor quantify total exposure, which may be of clinical significance. In a retrospective study of 786 IPF patients, the use of PPIs for $>4$ months was associated with reduced mortality whereas use for 2 or 3 months was not [21]. The introduction of categorisation by exposure duration however introduces immortal time bias and may explain some of the perceived benefit of therapy. A recent analysis by Tran et al. suggests that immortal time bias accounts for the beneficial effect of antacid therapy in many of the observational studies in IPF [29]. Thirdly, as this was not a randomised trial, it may be possible that patients who had the worst reflux were already on long-term treatment, mitigating their risk for disease progression. This may explain the fact that at baseline, patients on treatment had better FVC \%predicted and DLco \%predicted. There was however, no correlation between the severity of reflux symptoms in patients not on treatment and outcomes, suggesting that this is unlikely to be a key factor determining prognosis. Finally, the baseline characteristics between the treatment and non-treatment groups differed with patients on treatment tending to be older but have better lung function. Multivariable analysis adjusting for age, gender, smoking status, FVC and DLco however did not have any impact on outcomes. Despite the limitations, this study is one of the largest retrospective cohort studies of antacid therapy in IPF. It is also the first study to utilise the FSSG score, collected prospectively, in patients with IPF and shows that GORD symptom severity does not predict decline.

\section{Conclusion}

While further, robust randomised controlled trials are still needed, this study adds weight to the gathering evidence that antacid therapy may not be beneficial in IPF patients and that reflux directed therapy should be considered on an individual basis. While the severity of reflux symptoms does not predict IPF outcomes, it may help select patients who will benefit from GORD treatment for management of symptoms and the prevention of oesophageal injury. Our study also highlights the difficulty in defining GORD and highlights the need to standardise the GORD definition used in future prospective randomised studies if evidence of treatment benefit is to be accurately assessed.

\section{Abbreviations}

DLco: Diffusion capacity for carbon monoxide; FSSG: Frequency scale for symptoms of GERD; FVC: Forced vital capacity; GOR: Gastroesophageal reflux; GORD: Gastroesophageal reflux disease; H2RA: Histamine 2 receptor antagonists; ILD: Interstitial lung disease; IPF: Idiopathic pulmonary fibrosis; PFS: Progression free survival; PPI: Proton pump inhibitor

\section{Acknowledgements}

The writers thank all the participants and physicians who contribute to the Registry, as well as the Registry secretariat, data manager and co-coordinators who work tirelessly to gather and collate information. We also thank Alfred Health Solutions and Alfred Medical Imaging who are integral to the development and maintenance of the web-based radiology database.

\section{Funding}

Lung Foundation Australia has established the Australian IPF Registry with the generous support of a philanthropic family and unrestricted educational grants from Foundation partners Roche Products, Pty. Limited and

Boehringer Ingelheim and Project partner Bristol-Myers Squibb Australia. This analysis has been funded by support from the National Health and Medical Research Council (APP1066128) and the Centre of Research Excellence in Pulmonary Fibrosis (funded by the NHMRC and supported by Foundation Partner Boehringer Ingelheim and Program Partners Roche and Galapagos). All data analysis, interpretation and writing was performed by the authors of the manuscript without input from funding bodies.

\section{Availability of data and materials}

All datasets used and/or analysed during the current study are available from the corresponding author on reasonable request.

\section{Authors' contributions}

$\mathrm{HJ}, \mathrm{NG}$ and TC conceived the study. HJ analysed the data and together with $\mathrm{TC}$ and NG, wrote the manuscript. All authors contributed to data collection and read and approved the final manuscript.

\section{Ethics approval and consent to participate}

The Registry has ethical approval to operate in all States and Territories of Australia. All participants provide informed written consent to have their data collected and entered into the Registry. This analysis has ethical approval from the Sydney Local Health District ethics committee (protocol No X14-0264) to utilise de-identified data.

\section{Consent for publication}

Not applicable. This manuscript does not contain any individual person's data in any form.

\section{Competing interests}

The authors declare that they have no competing interests.

\section{Publisher's Note}

Springer Nature remains neutral with regard to jurisdictional claims in published maps and institutional affiliations.

\section{Author details}

${ }^{1}$ Department of Respiratory Medicine, Royal Prince Alfred Hospital, Missenden Road, Camperdown, Sydney, NSW 2050, Australia. ${ }^{2}$ Faculty of Medicine, University of Sydney, Sydney, NSW, Australia. ${ }^{3}$ National Health and Medical Research Council Centre of Research Excellence in Pulmonary Fibrosis, University of Sydney, Sydney, NSW, Australia. ${ }^{4}$ Department of Allergy and Respiratory Medicine, The Alfred Hospital, Melbourne, VIC, Australia. ${ }^{5}$ Faculty of Medicine, Monash University, Melbourne, VIC, Australia.

${ }^{6}$ Department of Respiratory Medicine, John Hunter Hospital, Newcastle, NSW, Australia. ${ }^{7}$ School of Medicine, University of Queensland, Brisbane, QLD, Australia. ${ }^{8}$ Queensland Lung Transplant Service, The Prince Charles Hospital, Brisbane, QLD, Australia. 'Department of Respiratory Medicine, Fiona Stanley Hospital, Perth, WA, Australia. ${ }^{10}$ Department of Respiratory Medicine, Royal Adelaide Hospital, Adelaide, SA, Australia. ${ }^{11}$ University of Tasmania, Hobart, TAS, Australia. ${ }^{12}$ Department of Thoracic Medicine, Royal Brisbane \& Women's Hospital, Brisbane, QLD, Australia. ${ }^{13}$ Lung Foundation Australia, Brisbane, QLD, Australia. ${ }^{14}$ Department of Respiratory Medicine, Princess Alexandra Hospital, Brisbane, QLD, Australia. ${ }^{15}$ Tissue pathology and 
Diagnostic Oncology, Royal Prince Alfred Hospital, Sydney, NSW, Australia. ${ }^{16}$ School of Medicine, Western Sydney University, Sydney, NSW, Australia. ${ }^{17}$ Department of Radiology, The Alfred Hospital, Melbourne, VIC, Australia. ${ }^{18}$ Department of Respiratory Medicine, Austin Hospital, Melbourne, VIC, Australia. ${ }^{19}$ Institute for Breathing and Sleep, Melbourne, VIC, Australia.

Received: 1 November 2018 Accepted: 11 April 2019

Published online: 03 May 2019

\section{References}

1. King TE Jr, Bradford WZ, Castro-Bernardini S, Fagan EA, Glaspole I, Glassberg MK, Gorina E, Hopkins PM, Kardatzke D, Lancaster L, Lederer DJ, Nathan SD, Pereira CA, Sahn SA, Sussman R, Swigris JJ, Noble PW. Group AS. A phase 3 trial of pirfenidone in patients with idiopathic pulmonary fibrosis. $N$ Engl J Med. 2014:370:2083-92.

2. Richeldi L, du Bois RM, Raghu G, Azuma A, Brown KK, Costabel U, Cottin V, Flaherty KR, Hansell DM, Inoue Y, Kim DS, Kolb M, Nicholson AG, Noble PW, Selman M, Taniguchi H, Brun M, Le Maulf F, Girard M, Stowasser S, Schlenker-Herceg R, Disse B, Collard HR, Investigators IT. Efficacy and safety of nintedanib in idiopathic pulmonary fibrosis. N Engl J Med. 2014;370: 2071-82.

3. King T, Tooze J, Schwarz M, Brown K, Cherniack R. Predicting survival in idiopathic pulmonary fibrosis. Am J Respir Crit Care Med. 2001;164:1171-81.

4. Raghu G, Freudenberger TD, Yang S, Curtis JR, Spada C, Hayes J, Sillery JK, Pope CE, Pellegrini CA. High prevalence of abnormal acid gastrooesophageal reflux in idiopathic pulmonary fibrosis. Eur Respir J. 2006;27: $136-42$

5. Lamas DJ, Kawut SM, Bagiella E, Philip N, Arcasoy SM, Lederer DJ. Delayed access and survival in idiopathic pulmonary fibrosis: a cohort study. Am J Respir Crit Care Med. 2011;184:842-7.

6. Savarino E, Carbone R, Marabotto E, Furnari M, Sconfienza L, Ghio M, Zentilin P, Savarino V. Gastro-oesophageal reflux and gastric aspiration in idiopathic pulmonary fibrosis patients. Eur Respir J. 2013;42:1322-31.

7. Tobin RW, Pope CE, Pellegrini CA, Emond MJ, Sillery JIM, Raghu G. Increased prevalence of gastroesophageal reflux in patients with idiopathic pulmonary fibrosis. Am J Respir Crit Care Med. 1998;158:1804-8.

8. Lee JS, Ryu JH, Elicker BM, Lydell CP, Jones KD, Wolters PJ, King TE Jr, Collard HR. Gastroesophageal reflux therapy is associated with longer survival in patients with idiopathic pulmonary fibrosis. Am J Respir Crit Care Med. 2011;184:1390-4.

9. Kreuter M, Ehlers-Tenenbaum S, Palmowski K, Bruhwyler J, Oltmanns U, Muley T, Heussel CP, Warth A, Kolb M, Herth FJ. Impact of comorbidities on mortality in patients with idiopathic pulmonary fibrosis. PLoS One. 2016;11:e0151425.

10. Kahrilas PJ. Gastroesophageal reflux disease. N Engl J Med. 2008;359:1700-7.

11. Savarino E, Bredenoord AJ, Fox M, Pandolfino JE, Roman S, Gyawali CP, On behalf of the international working Group for Disorders of gastrointestinal $\mathrm{M}$, function. Advances in the physiological assessment and diagnosis of GERD. Nat Rev Gastroenterol Hepatol. 2017;14:665.

12. Ronkainen J, Aro P, Storskrubb T, Johansson SE, Lind T, Bolling-Sternevald E, Vieth M, Stolte M, Talley NJ, Agreus L. Prevalence of Barrett's esophagus in the general population: an endoscopic study. Gastroenterology. 2005;129: 1825-31.

13. Raghu G, Rochwerg B, Zhang Y, Garcia CAC, Azuma A, Behr J, Brozek JL, Collard HR, Cunningham W, Homma S, Johkoh T, Martinez FJ, Myers J, Protzko SL, Richeldi L, Rind D, Selman M, Theodore A, Wells AU, Hoogsteden H, Schünemann HJ. An official ATS/ERS/JRS/ALAT clinical practice guideline: treatment of idiopathic pulmonary fibrosis. An update of the 2011 clinical practice guideline. Am J Respir Crit Care Med. 2015:192:e3-e19.

14. Lee JS, Collard HR, Anstrom KJ, Martinez FJ, Noth I, Roberts RS, Yow E, Raghu G. Anti-acid treatment and disease progression in idiopathic pulmonary fibrosis: an analysis of data from three randomised controlled trials. Lancet Respir Med. 2013;1:369-76.

15. Kreuter M, Wuyts W, Renzoni E, Koschel D, Maher TM, Kolb M, Weycker D, Spagnolo P, Kirchgaessler K-U, Herth FJF, Costabel U. Antacid therapy and disease outcomes in idiopathic pulmonary fibrosis: a pooled analysis. Lancet Respir Med. 2016;4(5):381-9.

16. Kreuter M, Spagnolo P, Wuyts W, Renzoni E, Koschel D, Bonella F, Maher TM, Kolb M, Weycker D, Kirchgässler K-U, Costabel U. Antacid therapy and disease progression in patients with idiopathic pulmonary fibrosis who received Pirfenidone. Respiration. 2017;93:415-23.
17. Raghu G, Crestani B, Bailes Z, Schlenker-Herceg R, Costabel U. Effect of antiacid medication on reduction in FVC decline with nintedanib. Eur Respir J. 2015;46.

18. Kusano M, Shimoyama Y, Sugimoto S, Kawamura O, Maeda M, Minashi K, Kuribayashi S, Higuchi T, Zai H, Ino K, Horikoshi T, Sugiyama T, Toki M, Ohwada T, Mori M. Development and evaluation of FSSG: frequency scale for the symptoms of GERD. J Gastroenterol. 2004;39:888-91.

19. Jo HE, Glaspole I, Grainge C, Goh N, Hopkins PM, Moodley Y, Reynolds PN, Chapman S, Walters EH, Zappala C, Allan H, Keir GJ, Hayen A, Cooper WA, Mahar AM, Ellis S, Macansh S, Corte TJ. Baseline characteristics of idiopathic pulmonary fibrosis: analysis from the Australian idiopathic pulmonary fibrosis registry. Eur Respir J. 2017;49.

20. Fidler L, Sitzer N, Shapera S, Shah PS. Treatment of gastroesophageal reflux in patients with idiopathic pulmonary fibrosis: a systematic review and meta-analysis. Chest. 2018;153(6):1405-15.

21. Lee CM, Lee DH, Ahn BK, Hwang JJ, Yoon H, Shin CM, Park YS, Kim N. Protective effect of proton pump inhibitor for survival in patients with gastroesophageal reflux disease and idiopathic pulmonary fibrosis. J Neurogastroenterol Motil. 2016;22(3):444-51.

22. Downing TE, Sporn TA, Bollinger RR, Davis RD, Parker W, Lin SS. Pulmonary histopathology in an experimental model of chronic aspiration is independent of acidity. Exp biol med (Maywood, NJ). 2008:233:1202-12.

23. Amigoni M, Bellani G, Scanziani M, Masson S, Bertoli E, Radaelli E, Patroniti $N$, Di Lelio A, Pesenti A, Latini R. Lung injury and recovery in a murine model of unilateral acid aspiration: functional, biochemical, and morphologic characterization. Anesthesiology. 2008;108:1037-46

24. Appel JZ, Lee SM, Hartwig MG, Li B, Hsieh C-C, Cantu E, Yoon Y, Lin SS, Parker W, Davis RD. Characterization of the innate immune response to chronic aspiration in a novel rodent model. Respir Res. 2007;8:87.

25. Raghu G, Pellegrini CA, Yow E, Flaherty KR, Meyer K, Noth I, Scholand MB, Cello J, Ho LA, Pipavath S, Lee JS, Lin J, Maloney J, Martinez FJ, Morrow E, Patti MG, Rogers S, Wolters PJ, Yates R, Anstrom KJ, Collard HR. Laparoscopic anti-reflux surgery for the treatment of idiopathic pulmonary fibrosis (WRAP-IPF): a multicentre, randomised, controlled phase 2 trial. Lancet Respir Med. 2018;6(9):707-714.

26. Bédard Méthot D, Leblanc É, Lacasse Y. Meta-analysis of gastroesophageal reflux disease and idiopathic pulmonary fibrosis. Chest. 2019;155(1):33-43. https://doi.org/10.1016/j.chest.2018.07.038.

27. Katz PO, Gerson LB, Vela MF. Guidelines for the diagnosis and management of gastroesophageal reflux disease. Am J Gastroenterol. 2013;108:308-28 quiz 29.

28. Johannson KA, Strâmbu I, Ravaglia C, Grutters JC, Valenzuela C, Mogulkoc N, Luppi F, Richeldi L, Wells AU, Vancheri C, Kreuter M, Albera C, Antoniou KM, Altinisik G, Bendstrup E, Bondue B, Borie R, Brown KK, Camus P, Castillo D, Collard HR, Cottin V, Crimi N, Ferrara G, Fischer A, Gauldie J, Geiser T, Guenther A, Hambly N, Hansell DM, Harari S, Jones MG, Keane M, Ley B, Maher TM, Molina-Molina M, Palmucci S, Poletti V, Prasse A, Rottoli P, Spagnolo P, Sterclova M, Torrisi S, Tsitoura E, Vasakova M, Walsh SL, Wijsenbeek MS, Wuyts WA. Antacid therapy in idiopathic pulmonary fibrosis: more questions than answers? Lancet Respir Med. 2017;5:591-8.

29. Tran T, Suissa S. The effect of anti-acid therapy on survival in idiopathic pulmonary fibrosis: a methodological review of observational studies. Eur Respir J. 2018;51.

Ready to submit your research? Choose BMC and benefit from:

- fast, convenient online submission

- thorough peer review by experienced researchers in your field

- rapid publication on acceptance

- support for research data, including large and complex data types

- gold Open Access which fosters wider collaboration and increased citations

- maximum visibility for your research: over $100 \mathrm{M}$ website views per year

At $\mathrm{BMC}$, research is always in progress.

Learn more biomedcentral.com/submission 